\title{
Community Based Borewell Irrigation Systems for Improving Productivity and Water Use Efficiency in Dryland Agriculture
}

\author{
K.V. Rao, S. Deepika*" and R. Rejani \\ ICAR-Central Research Institute for Dryland Agriculture, Hyderabad, Telangana, India \\ *Corresponding author
}

\section{Key words \\ Ground water sharing, Community irrigation, Sprinkler irrigation, Water use efficiency \\ Article Info \\ Accepted: 07 October 2018 Available Online: 10 November 2018}

\section{A B S T R A C T}

Groundwater is an important source for irrigation in large tracks of India. This source has been considered as infinite and used indiscriminately without any disregard to recharge prospects. Reducing the over exploitation of ground water and its optimal utilization for irrigation is the need of the hour especially in low rainfall areas. In order to address this problem, Andhra Pradesh Government has started a project on Andhra Pradesh Draught Adaptation Initiative (APDAI) in the year 2012 in which water has to be shared by Borewell owners (BWO) and Non borewell owners (NBWO) by pooling the bore wells and irrigating through micro irrigation systems. The present study was undertaken for ground water sharing groups from the three mandals (cluster of villages) of Ananthapur district in Andhra Pradesh. The main objective of the present study was to assess water use efficiency and evaluation of overall impact of the Community Based Sprinkler Irrigation system CBSIS in three mandals viz. Garladinne, Nallamada and Goothy in poverty alleviating of the participants in comparison to before CBSIS. The study recorded an improvement in WUE under critical irrigation (CI) from 0.35 to $2.0 \mathrm{~kg}$ (ha-mm) $)^{-1}$ in Yerraguntla, 0.32 to $2.46 \mathrm{~kg}$ (ha-mm) $)^{-1}$ in Edulavanka and 0.26 to $2.02 \mathrm{~kg}$ (ha-mm) ${ }^{-1} \mathrm{~T}$ Kothapally. It was also observed that there were remarkable changes in the livelihood, cultivated area and crop production under rainfed conditions with critical irrigation. Further the study recommended that the revised operating schedules can bring more area under irrigation with qualitative and quantitative improvement of the produce during kharif and rabi seasons. The results provide the insight for the adaptation of CBSIS to encounter the drought situation as a group.

\section{Introduction}

Agriculture is backbone of rural population in India. Around $80 \%$ of the area is under rainfed agriculture, which plays a major role in global food supply (Aguilar, 2011; Latha et al., 2012). Around $57 \%$ of the agricultura area is predominantly rainfed in Andhra Pradesh. Due to uneven distribution and magnitude of rainfall, farmers started pumping the ground water for irrigation. Construction of bore wells and pump sets actually triggered more rapid decline of water levels and these structures, by virtue of their depth, are capable of yielding more water than the dug wells (Rukmani and Manjula). Therefore, major investment incurred by the farmer in competitive digging of bore wells compared to adjacent farmers 
which ultimately resulted in failure of wells due to over exploitation and thus leaving the farmer in debt.

The water is a scarce commodity and it must be used in agriculture judiciously and in an efficient manner with the objective to obtain better economic returns without jeopardize the future sustainability. In this context the concept of conjunctive use of surface and ground water is coined since few decades. Ground water plays an important role in agriculture as it is the reliable source than surface water for irrigation.

Though agriculture remains the most important economic activity of rural households in India, most of the farmers are leaving the lands barren due to lack of water for irrigation owing to failure of bore wells. Deterioration of ground water quality and declining ground water levels are very common. Severity of water scarcity for irrigation has drawn the attention of many researchers towards development, conservation and management strategies of water. Many new developments took place for converting flood irrigation to pressurized irrigation system, porous pipe irrigation, precision farming etc for conserving water (Ward, 2014). Despite the fact that Ananthapur district falls under rain shadow region, agriculture remains the important source for economic activity. So, irrigation is obligatory to protect the rainfed crop. Dry spells induce moisture stress and have a major impact on growth and development when they occur at some life history stages. Dry spells and wet spells can also trigger the growth of pests/diseases/weeds and hence have impact on the yield. Ground nut which is the major crop of Ananthapur district may show the impact on the operational efficiency, as in the case of an intense dry spell during harvest which results in difficulty in retrieving all the pods from the hard soil (Gadgil et al., 1999).
Other crops grown in these areas are paddy, red gram and castor (Rukmani and Manjula).

The prime objective of applying water to the plant is according to its requirement which is dictated by soil and environment conditions and many other factors. The institutional approach to manage groundwater by arresting over-exploitation of groundwater and for mitigating environmental consequences is through establishment of a regulatory framework. Towards this end the Government of Andhra Pradesh introduced the Andhra Pradesh Drought Adaptation Initiative (AP DAI) implemented in Ananthapur district. The project aims to protect kharif crops during prolonged dry spells by pooling the bore wells to share water among Bore well Owners (BWO) and Non Bore Well Owners (NBWO) by forming a community.

Since late seventies, various demand curtailing strategies have been tried to improve the water use efficiency in agriculture (Narayanamoorthy,2003).On-farm irrigation efficiency of properly designed and managed sprinkler irrigation method is upto60 percent for cereals, pulses and vegetable crops (Sivanappan, 1998). Micro irrigation is the advanced irrigation technology for the arid and semiarid regions as it is suitable for almost all crops, terrains, soils and climatic conditions.

The focus of the study is to analyze the Community Based Sprinkler Irrigation System (CBSIS) and recommendations to build resilience of the system and efficiency with the available resources, evaluation of overall impact of the CBSIS and development of appropriate strategies for upscaling.

Micro irrigation system performance depends on optimal operating pressure and the irrigation schedules. Irrigation schedule is the guide for the farmers when to irrigate and how 
much time to irrigate to meet the crop water requirement. Sustainability of the system depends on the optimal utilization of the natural resources without environmental risk. Provincial government of Spain has started Irrigation advisory services for filling the gap between the technology and practice followed by the farmer by providing areas, the operating schedules for an area of 1,00,000 ha in water scarce (Smith and Munoz, 2002; Ortega et al., 2005; Montoro et al., 2011).

For the present study with a view to replicate the entire district condition, 3 groups are selected erratically from three different mandals out of 14 groups (Table 1) in the district. Each farmer of the three groups was interviewed personally to find the prevailing site conditions and operation methods and strategies followed (Dumaru, 2010). For the three groups Designs and Estimations were prepared by WASSAN (NGO) by considering the field situation and local government guidelines. Estimations were submitted to Joint Director Agriculture, Dept. of Agriculture, AP.

The system (CBSIS) is designed to irrigate BWO field and share water to NBWO only to save the crop during prolonged dry spells during kharif season by giving critical Irrigation $(\mathrm{CI})$. It is observed that borewells are being operated daily to irrigate the BWO field which resulted in over irrigation and percolation losses. Optimal operating schedules were recommended for the study groups to further increase the water uses efficiencies. Site wise operating schedules were recommended by considering the bore well yield, number of available sprinkler sets and crop water requirements. Using Hargreaves method and 30 years data average reference evapotranspiration for Ananthapur district was assessed for calculating crop water requirement of groundnut crop (Deepika, 2016).

\section{Materials and Methods}

An observational study was conducted in the fields of CBSIS to assess and provide suitable technical recommendations to further improve the usage of ground water irrigation system effectively.

\section{Study area}

Ananthapur district which is southern most of Andhra Pradesh is located in rain shadow region. Study area details shown in the Table 2 and available water and the site conditions are presented in the Table 3. Three groups from three different mandals located in Ananthapur district are Yarraguntla village of Garladinnemandal, Eedulavanka village of Nallamadamandals and T-Kothapally village of Gootymandal. The study area details are depicted in Figure 1.

\section{Climate and soil conditions}

The district lies in the rain- shadow region of Andhra Pradesh with a normal rainfall of 553 $\mathrm{mm}$ out of which $330 \mathrm{~mm}$ is received during south west monsoon i.e. kharif season. The soils of these regions are red soils. The texture is loam to sandy loam. This is mostly suited to irrigated, dry land crops. The depth of soil is on an average $180 \mathrm{~cm}$ in Ananthapur region while the depth of top layer is nearly $40-50 \mathrm{~cm}$ which is covering one third of the soil. According to the USDA land capability classification, these soils belong to Class II type. Soils in this class require more than ordinary management practices for obtaining optimum production and for maintaining productivity (Michael, 2014).

\section{Site condition}

Yerraguntla Group: This group consists of 25 farmers, out of which 4 are bore well owners with 4.86 ha of land holding are sharing water 
with non borewell farmers. A particular farmer is holding 0.81ha of holding on one side and the rest of his holding on the other side of the periphery of the group. So, he has already laid PVC pipe for conveying irrigation water to his field is being used for pooling of bore wells for the group. Hence the size of the group is large so as to utilize the available resources. Availability of water is measured during summer season by collecting the water in a container of known capacity and the time required to fill is noted. The pump has been operated for $6 \mathrm{hrs}$ to know whether there is any variation or decrease in discharge if the pump is operated continuously for finding the safe discharges of the bore wells measurements were taken up at each bore well during 2015 June. Combine yield of bore wells are recorded as 41.921ps $\left(905.54 \mathrm{~m}^{3} / 6 \mathrm{hr}\right)$

Eedulavanka Group: 19 farmers formed a group for water sharing. 7farmers with 8.91 ha of land is sharing water with rest of the 12 farmers with a land of 8.9ha. The available water for irrigation is 35.991ps (777.33 $\mathrm{m}^{3} / 6 \mathrm{hr}$ ) for $17.81 \mathrm{ha}$.

T-Kothapally group: The total irrigated area of the group is 17.5 ha of 14 farmers of which four farmers owning bore wells with total discharge of $11.331 \mathrm{ps}\left(243.9 \mathrm{~m}^{3} / 6 \mathrm{hr}\right)$.

\section{Pipeline network for pooling borewells}

In Yerraguntla group, the existing pipe line in the field was used for SPSIS which was laid for conveying water from the bore wells on the other side of the road.

Particular farmer is holding 0.81 ha on the other side of the road which is nearly $2.5 \mathrm{~km}$ away and around 4 ha in the CBSIS group. In other two groups i.e. Eedulavanka and TKothapally, new pipe line was sanctioned by the Department of Agriculture, Andhra Pradesh, as a part of SPSIS.

\section{Recommended irrigation schedules}

\section{Prevailing operating schedules}

Interaction with the farmers revealed that bore well owners are irrigating the field everyday by leaving each set to operate for $3 \mathrm{hrs}$ and then shifting to second patch operating again for $3 \mathrm{hrs}$ resulting in over irrigation. In turn, this is leading to deep percolation of water below the root zone, leaching of micronutrients and wastage of pumped water and erosion of soil. Spacing between sprinkler to sprinkler and lateral to lateral is $12 \mathrm{~m}$ which is being maintained in all the fields without overlapping. NBWO are getting only the critical irrigation once or twice during the crop period.

\section{Site specific recommendations}

Considering the available water, sprinkler irrigation sets sanctioned for each group and power availability for agriculture lands site specific irrigation schedules are suggested. For Yerraguntla, Mahabubsubhani group, the total group is divided in to 6 subdivisions and allowed to irrigate in 5 to 6 days, with 8.05 ha and 6.81 ha can be irrigated per day during kharif and rabi seasons respectively. Each subgroup can operate for $16.24 \mathrm{~min}$ to meet the water requirement (WR) of groundnut crop, without considering the precipitation during kharif. Entire area of the group can be irrigated in 5 days. However, during rainy season few irrigations can be skipped according to precipitation. Dunnikota, Eedulavanka group the land holding of 17.81 ha can be irrigated by sub dividing in to 5 sections. Maximum 3.64 ha can be irrigated in a section per one day with the available water. Available water per day is $621 \mathrm{~m}^{3} /$ day, the required water for 8.9 ha land is nearly equal to available water during kharif and rabi seasons. Sprinkler irrigation system has to operate for $16.24 \mathrm{~min}$ to meet the water 
requirement (WR) of groundnut crop. To mee the crop water requirement of total land of BWO and NBWO, only 20 days the water has to be pumped during the crop period. Tkothapally, Gangireddy group has a holding of 9.71 ha and 6 sprinkler sets with an available water $194 \mathrm{~m}^{3} /$ day. Accordingly maximum 2.98 ha can be irrigated per day. The total WR of the group can be met within 4 days. Time of operation for each section is considered as $30 \mathrm{~min}$ by providing some grace period for shifting (Deepika, 2016). Sustainable CBSIS is possible with equitable and dependable water distribution (Kezbekov, 2009).

\section{Cropwater use efficiency (CWUE)}

Crop water use efficiency is used to find the efficiency of the irrigated water used. It is defined as the ratio of the mass of economic yield per water lost by plant through transpiration. In the present case study, critical irrigation is provided to the NBWO to protect the kharif crop.

$$
\text { Crop water use efficiency }(C W U E \quad)=\frac{Y}{E T c}
$$

Where,

CWUE = Crop water use efficiency [kg (ha$\mathrm{mm})^{-1}$ ]

$\mathrm{Y}=$ Crop yield $\left(\mathrm{kg} \mathrm{ha}^{-1}\right)$

ETc $=$ Potential crop evapotranspiration $(\mathrm{mm})$

\section{Results and Discussion}

\section{Crop area}

Before inception of CBSIS 2012, the area under irrigated cultivation of the bore well owners in Yerraguntla and Eedulavanka groups was nearly $50 \%$ of the land holding.
Farmers cultivated paddy through flood irrigation. Since 2012 June, after awareness campaign to restrict competitive digging and ensure minimum yields from the BWO and NBWO fields by adapting CBSIS, the area under cultivation has been improved by adapting controlled irrigation and crop diversification. As sprinklers apply water more efficiently and uniformly than typical surface irrigation systems, they produce more yields for each quantity applied per unit area (Hill and Heaton, 2001) and also increased the area under cultivation. Area under irrigated cultivationin Yerraguntla group $(87 \%)$ is much higher than Edulavanka (50\%) and TKothapally (75\%) groups (Table 4). Though the studies revealed that small commons can be organized more efficiently in terms of production and performance (Hector, 2011; Bedeke, 2011), this is an exceptional case being organized and executed efficiently.

\section{Crop production}

Before inception of CBSIS, bore well owners (BWO) used to cultivate paddy through flood irrigation and the NBWO land was cultivated under rainfed condition. After inception of CBSIS, BWO also adapted sprinkler irrigation system. Under CBSIS all the farmers of Edulavanka and T-Kothapally group has drawn minimum yields by overcoming the losses during prolonged dry spells (Table 5). Under irrigated condition, BWO field yields also increased (Table 6). Yields of completely irrigated fields before and after inception of CBSIS has showed drastic increase in the yields because of controlled irrigation.

Yerraguntla: Before CBSIS, 4.86 ha of BWO land was under fully irrigated and yield were nearly $473 \mathrm{~kg} / \mathrm{ha} .10$ ha of land was cultivated under rainfed condition with average yield of $160 \mathrm{~kg} / \mathrm{ha}$ and rest of 22.94 ha has shown negligible yields under rainfed condition. After initiation of CBSIS, 2.43 ha of BWO 
under fully irrigated and 17 ha under critical irrigation with an average yield of $1465 \mathrm{~kg} / \mathrm{ha}$ and $913.9 \mathrm{~kg} / \mathrm{ha}$ respectively. Around 18.32 ha of land has shown negligible yields due to different reasons along with improper planning of operating schedules

Eedulavanka: Before commencement of CBSIS, 8.91 ha of BWO land was fully irrigated and obtained an average yield of $948.7 \mathrm{~kg} / \mathrm{ha}$, and 4.86 ha was under rainfed cultivation given the average yield of 144 $\mathrm{kg} / \mathrm{ha}$ and 5.3 ha of land showed negligible yields. Since inception of CBSIS, only 4.45 ha of land was under fully irrigated and rest of the 4.45 ha of land of BWO was shifted to critical irrigation. Around, 4.45 ha of BWO land provided with 3 critical irrigations, showed average yields of $1120 \mathrm{~kg} / \mathrm{ha}$ and rest of 8.9 ha of NBWO field with 2 critical irrigations showed an average yield of 866 $\mathrm{kg} / \mathrm{ha}$.

T-kothapally: This group has experienced average yield of $955.07 \mathrm{~kg} / \mathrm{ha}$ in 2.43 ha under irrigated condition and $120 \mathrm{~kg} / \mathrm{ha}$ under rainfed condition from 3.44 ha. Out of 9.71 ha of total group area 3.85 ha showed negligible yields before inception of CBSIS. After CBSIS, 2 ha was under fully irrigated condition received an average yield of 1062.1 $\mathrm{kg} / \mathrm{ha}$. Remaining 7.69 ha of land (BWO and NBWO) with two critical irrigations received an average yield of $1120.48 \mathrm{~kg} / \mathrm{ha}$.

\section{Crop water use efficiencies}

The effect of three CBSIS on crop production was studied by collecting the data from the farmers through field survey. Before the inception of CBSIS, farmers used to cultivate rainfed crops like groundnut, mustard, sunflower, ragi (small millet) and pearl millet in most of the area and BWO used to cultivate rice crop under irrigated conditions. Due to improper distribution of rainfall and prolonged dry spells even during kharif season, farmers have experienced complete crop loss under rainfed cultivation.

Commissioning of the CBSIS had drastically changed the cropping pattern of both BWO and NBWO. With the available ground water, the farmers were educated to diversify from paddy to low water consuming crops like groundnut, maize, pigeon pea etc. which are suitable for Ananthapur climatic conditions. However, to understand the influence of CBSIS on crop production, crop water use efficiency was estimated.

The average crop evapotranspiration (ETc) during monsoon season for groundnut was 325 $\mathrm{mm}$ for kharif season and corresponding yields for the three sites before and after inception of CBSIS are shown in Table 7 and 8 respectively. The crop WUE under rainfed condition was $0.3 \mathrm{~kg} /($ ha-mm) before CBSIS and is increased to $2 \mathrm{~kg} /($ ha-mm) under CI condition. CWUE has shown increasing trend in all the 3 sites after CBSIS in case of irrigated, rainfed and CI conditions.

\section{Socio economic impact of CBSIS}

To cope with the drought the owner farmers(large farmer) are adopting various agronomical measures like crop intensification, additional bore wells and over exploitation of ground water in comparison to small farmer ( $<1$ ha land) and the tenant farmers (Habiba et al., 2012).

Impact of CBSIS empathizes the socioeconomic impacts of the groups before and after adapting the CBSIS. In case of rainfed agriculture, prolonged dry spells always results in crop failure, decreases the yield of food grains, livestock production, and weakens the income of agrarian households. It results in unemployment of unskilled labor and loss of their time in water collection 
activities. All of these impacts ultimately weakens the financial condition of farmers. All the participating farmers in the three communities have alleviated poverty due to continuous crop failure due to erratic monsoon.

\section{Environmental impacts}

The proposed activities promoted better use of land and water through adoption of improved irrigation schedules. The impacts turned the zero and marginal productive land into full production land.

CBSIS facilitated to adapt crop production and minimum guarantee returns irrespective of rainfall variability.

Possibility of increased groundwater recharge and reduced the digging of additional bore wells.

Increased small farmer household income

Enhanced inter and intra community interaction and adoption of new improved technologies.

Adaption of micro irrigation resulted in minimizing the erosion losses compared to flood irrigation.

\section{Management and issues}

People's participation in irrigation management is a key to success in the management of irrigation project particularly in improving water use efficiency. One of the possible ways for long term sustainability of common sharing is through local selfgovernance where individuals themselves managed to collaborate around a scarce resource and (Ostrom, 1999). Also emphasizes that the small group size, well defined boundaries on resources and user groups, and ease of monitoring and enforcement (Ostorm
1999; Agrawal, 2005). The prime objective of CBSIS is to protect the rainfed crop by providing the critical irrigation, equity in sharing and distribution of water and is the primary requirement for the success of the project.

Participant farmers have to sign an agreement in front of MRO (Mandal Revenue Officer) and JDA (Joint Director Agriculture), Agriculture Department for 10 years, that BWO will share GW to protect the kharif crop among the group and no additional/new borewells will be dug. Farmer's contribution of Rs. 6,250/- per hectare has been collected by the group from the participant farmers, which is used for the procurement of material and maintenance of the system. The fund collected was maintained in a bank with joint account. The account holders are one from farmer group and the member from the concerned PFA working for the community. For the procurement of Micro irrigation system (MIS), 90\% of the system cost is provided by the Agriculture department as subsidy. The remaining $10 \%$ will be met from the fund maintained by the farmer's contribution.

\section{Role of NGO}

WASSAN acted as the Lead Technical Agency (LTA) at state level and 3 NGO's acted as Program Facilitating Agency (PFA) at Mandal level viz. REDs, RIDS and HANDS. LTA prepares group wise project estimates and submit to the joint director Agriculture, Agricultural Department. PFA's will work for coordination among different government departments for departmental works on behalf of the farmers group by conducting regular meetings among the group, resolving the conflicts, creating awareness among the farmers about latest schemes and techniques developed by government organizations for the betterment of farmers. 
Table.1 Details showing mandal wise groups and area covered under CBSIS in Ananthapur district

\begin{tabular}{|c|c|c|c|c|c|c|c|c|c|c|c|}
\hline \multirow{2}{*}{$\begin{array}{l}\text { S. } \\
\text { No. }\end{array}$} & \multirow{2}{*}{$\begin{array}{l}\text { Name of } \\
\text { the NGO }\end{array}$} & \multirow[t]{2}{*}{ Name of the group } & \multirow{2}{*}{$\begin{array}{l}\text { Name of } \\
\text { the village }\end{array}$} & \multirow{2}{*}{$\begin{array}{l}\text { Name of } \\
\text { the mandal }\end{array}$} & \multirow{2}{*}{$\begin{array}{l}\text { No of } \\
\text { bore } \\
\text { wells }\end{array}$} & \multirow{2}{*}{$\begin{array}{c}\text { No of } \\
\text { bore } \\
\text { well } \\
\text { farmers }\end{array}$} & \multirow{2}{*}{$\begin{array}{c}\text { No of } \\
\text { non } \\
\text { borewell } \\
\text { farmers }\end{array}$} & \multirow{2}{*}{$\begin{array}{c}\text { Total } \\
\text { no. of } \\
\text { farmers }\end{array}$} & \multicolumn{3}{|c|}{ Total Rainfed land in ha } \\
\hline & & & & & & & & & $\begin{array}{c}\text { Area of } \\
\text { borewell } \\
\text { farmers } \\
\text { (ha) }\end{array}$ & $\begin{array}{c}\text { Area of } \\
\text { non } \\
\text { borewell } \\
\text { farmers } \\
\text { (ha) }\end{array}$ & $\begin{array}{l}\text { Total } \\
\text { area } \\
\text { (ha) }\end{array}$ \\
\hline 1 & \multirow[t]{4}{*}{$\begin{array}{l}\text { WASSA } \\
\mathrm{N}\end{array}$} & Thakkillagadda RMG & $\begin{array}{l}\text { Devireddyp } \\
\text { alli }\end{array}$ & $\begin{array}{l}\text { Nallacheruv } \\
\mathrm{u}\end{array}$ & 3 & 9 & 6 & 15 & 6.14 & 2.19 & 8.32 \\
\hline 2 & & $\begin{array}{l}\text { Chinnamarapuchenu } \\
\text { RMG }\end{array}$ & $\begin{array}{l}\text { Pallevandla } \\
\text { palli }\end{array}$ & Gandlapenta & 4 & 6 & 16 & 22 & 4.86 & 11.74 & 16.60 \\
\hline 3 & & Sreenivasa RMG & $\begin{array}{l}\text { Karanamvar } \\
\text { ipalli }\end{array}$ & Gandlapenta & 4 & 9 & 8 & 17 & 6.88 & 6.07 & 12.96 \\
\hline 4 & & Malikadachenu & $\begin{array}{l}\text { Narasappag } \\
\text { aripalli }\end{array}$ & & 3 & 3 & 13 & 16 & 2.23 & 10.93 & 13.16 \\
\hline 5 & \multirow[t]{3}{*}{ HANDS } & Peddacheruvu & T.Kthapalli & Gooty & 8 & 12 & 15 & 27 & 9.31 & 12.35 & 21.66 \\
\hline 6 & & Mamidimandla & & & 4 & 4 & 13 & 17 & 2.4 & 7.29 & 9.69 \\
\hline 7 & & Kalivigundla & & & 4 & 3 & 17 & 20 & 2.23 & 14.57 & 16.80 \\
\hline 8 & \multirow[t]{2}{*}{$\mathrm{AF}$} & Zuttonokunta & Korrakodu & Kuderu & 5 & 4 & 10 & 14 & 1.62 & 15.38 & 17.00 \\
\hline$\overline{99}$ & & Tellarallagutta & & & 8 & 5 & 10 & 15 & 4.25 & 8.10 & 12.35 \\
\hline 10 & \multirow[t]{2}{*}{ REDS } & Girremmagutta & Donnikota & Nallamada & 5 & 8 & 10 & 18 & 5.06 & 6.88 & 11.94 \\
\hline 11 & & Edulavanka & & & 7 & 8 & 11 & 19 & 8.91 & 8.90 & 17.81 \\
\hline 12 & \multirow[t]{3}{*}{ RIDS } & Sirivaram & Sirivaram & Garladinne & 5 & 5 & 13 & 18 & 5.26 & 17.00 & 22.27 \\
\hline 13 & & Mahaboobsubhani & Yerraguntla & & 7 & 4 & 21 & 25 & 2.43 & 35.30 & 37.80 \\
\hline 14 & & Yarraguntla & & & 6 & 3 & 11 & 14 & 3.24 & 10.93 & 14.17 \\
\hline \multicolumn{5}{|c|}{ Grand Total } & 73 & 84 & 170 & 254 & 58.57 & 161.7 & $\begin{array}{c}220.2 \\
7\end{array}$ \\
\hline
\end{tabular}

Table.2 Details showing the location of study area (three CBSIS sites)

\begin{tabular}{|c|c|c|c|}
\hline $\begin{array}{c}\text { S. } \\
\text { No. }\end{array}$ & Village and Mandal & Longitude & Latitude \\
\hline 1 & Yerraguntla, Garladinne, & $77^{0} 31^{\prime} 11^{\prime \prime}$ to $77^{0} 31^{\prime} 29^{\prime \prime}$ & $\begin{array}{l}14^{0} 49^{\prime} 12^{\prime \prime} \text { to } 14^{0} 49^{\prime} \\
33^{\prime \prime}\end{array}$ \\
\hline 2 & Eedulavanka, Nallamada & $78^{0} 01^{\prime} 19^{\prime \prime}$ to $78^{0} 01^{\prime} 47^{\prime \prime}$ & $\begin{array}{l}14^{0} 04^{\prime} 56^{\prime \prime} \text { to } 14^{0} 05^{\prime} \\
15^{\prime \prime}\end{array}$ \\
\hline 3 & T-Kothapally, Goothy & $77^{0} 41^{\prime} 49^{\prime \prime}$ to $77^{0} 41^{\prime} 52^{\prime \prime}$ & $\begin{array}{l}15^{0} 07^{\prime} 53^{\prime \prime} \text { to } 15^{0} 08^{\prime} \\
07^{\prime \prime}\end{array}$ \\
\hline
\end{tabular}

Table.3 Showing the details of the available resources at study sites

\begin{tabular}{|c|c|c|c|c|c|c|c|}
\hline \multirow[t]{2}{*}{ Group } & \multicolumn{2}{|c|}{ BWO } & \multicolumn{2}{|c|}{ NBWO } & \multirow{2}{*}{$\begin{array}{c}\text { No. of } \\
\text { BW }\end{array}$} & \multirow{2}{*}{$\begin{array}{c}\text { Available } \\
\text { Water (6h of } \\
\text { pumping), } \text { m }^{3} / \\
\text { day }\end{array}$} & \multirow{2}{*}{$\begin{array}{c}\text { Total } \\
\text { Area, } \\
\text { ha }\end{array}$} \\
\hline & $\begin{array}{l}\text { No. of } \\
\text { Farmer } \\
\text { s }\end{array}$ & $\begin{array}{c}\text { Area, } \\
\text { ha }\end{array}$ & $\begin{array}{c}\text { No. of } \\
\text { Farmers }\end{array}$ & $\begin{array}{c}\text { Area, } \\
\text { ha }\end{array}$ & & & \\
\hline Yerraguntla & 4 & 4.86 & 21 & 32.89 & 7 & 724.00 & 37.75 \\
\hline Eedulavanka & 7 & 8.91 & 12 & 8.91 & 7 & 621.86 & 17.82 \\
\hline T-Kothaapally & 4 & 2.43 & 13 & 7.29 & 4 & 195.00 & 9.72 \\
\hline
\end{tabular}

(Note: BW- Bore wells, BWO- Bore well owners, NBOW- Non Borewell owners) 
Table.4 Area under cultivation before and after inception of Community based sprinkler irrigation system

\begin{tabular}{|c|c|c|c|c|c|c|c|c|}
\hline \multirow[t]{2}{*}{ Mandal } & \multirow[t]{2}{*}{ Village } & \multicolumn{4}{|c|}{ Area under irrigation before CBSIS } & \multicolumn{3}{|c|}{$\begin{array}{l}\text { Area under rainfed/CI after } \\
\text { CBSIS }\end{array}$} \\
\hline & & Crop & $\begin{array}{l}\text { Irrigated } \\
\text { Area (ha) }\end{array}$ & Crop & $\begin{array}{l}\text { Rainfed } \\
\text { Area (ha) }\end{array}$ & $\begin{array}{l}\text { Irrigated } \\
\text { Area (ha) }\end{array}$ & $\begin{array}{c}\text { CI } \\
\text { Area } \\
\text { (ha) }\end{array}$ & $\begin{array}{c}\text { Total } \\
\text { (ha) }\end{array}$ \\
\hline Garladinne & Yerraguntla & Paddy & 4.9 & Groundnut & 10.32 & 2.4 & 35.3 & 37.8 \\
\hline Nallamada & Eedulavanka & Paddy & 8.9 & Groundnut & 4.86 & 4.9 & 12.9 & 17.8 \\
\hline Gooty & T-kothapally & Paddy & 2.4 & Groundnut & 7.29 & 2.0 & 7.7 & 9.7 \\
\hline
\end{tabular}

Table.5 Yields before inception of Community based sprinkler irrigation system under irrigated and rainfed condition

\begin{tabular}{|c|c|c|c|c|c|c|c|}
\hline \multirow[t]{3}{*}{ Village } & \multicolumn{7}{|c|}{ Yields before CBSIS } \\
\hline & \multicolumn{3}{|c|}{ Fully Irrigated } & \multicolumn{3}{|c|}{ Rainfed Cultivation } & \multirow{2}{*}{$\begin{array}{l}\text { Area with } \\
\text { negligible } \\
\text { yield (ha) }\end{array}$} \\
\hline & $\begin{array}{l}\text { Area under } \\
\text { Irrigation } \\
\text { (ha) }\end{array}$ & $\begin{array}{l}\text { Yield } \\
\text { (kg) }\end{array}$ & Yield (kg/ha) & $\begin{array}{l}\text { Area under } \\
\text { rainfed } \\
\text { cultivation } \\
\text { (ha) }\end{array}$ & Yield (kg) & $\begin{array}{c}\text { Yield } \\
\text { (kg/ha) }\end{array}$ & \\
\hline Yerraguntla & 4.9 & 2300.0 & 473.4 & 10.0 & 1600.0 & 160.0 & 22.9 \\
\hline Eedulavanka & 8.9 & 8450.0 & 948.7 & 9.0 & 1300.0 & 144.4 & 5.3 \\
\hline T-kothapally & 2.4 & 2320.0 & 955.1 & 3.4 & 1020.0 & 120.0 & 3.9 \\
\hline
\end{tabular}

Table.6 Yields after inception of Community based sprinkler irrigation system under irrigated and critically irrigated condition

\begin{tabular}{|c|c|c|c|c|c|c|c|c|c|c|}
\hline \multirow[t]{3}{*}{ Village } & \multicolumn{10}{|c|}{ Area after CBSIS under Irrigated/CI } \\
\hline & \multicolumn{3}{|c|}{ Fully Irrigated } & \multicolumn{3}{|c|}{ Two Critical Irrigation } & \multicolumn{3}{|c|}{ Three Critical Irrigation } & \multirow{2}{*}{$\begin{array}{c}\text { Area } \\
\text { with } \\
\text { negligi } \\
\text { ble } \\
\text { yield } \\
\text { (ha) }\end{array}$} \\
\hline & $\begin{array}{c}\text { Area } \\
\text { Fully } \\
\text { Irrigated } \\
\text { (ha) }\end{array}$ & $\begin{array}{c}\text { Yield } \\
\text { (kg) }\end{array}$ & $\begin{array}{c}\text { Yield } \\
\text { (kg/ha) }\end{array}$ & $\begin{array}{c}\text { Area } \\
\text { under } \\
\text { CI (ha) }\end{array}$ & $\begin{array}{c}\text { Yield } \\
\text { (kg) }\end{array}$ & $\begin{array}{c}\text { Yield } \\
\text { (kg/ha) }\end{array}$ & $\begin{array}{c}\text { Area } \\
\text { under } \\
\text { CI (ha) }\end{array}$ & $\begin{array}{c}\text { Yield } \\
\text { (kg) }\end{array}$ & $\begin{array}{c}\text { Yield } \\
\text { (kg/ha) }\end{array}$ & \\
\hline Yerraguntla & 2.4 & 3560.0 & 1465.5 & 17.0 & 15540.0 & 913.9 & & & & 18.3 \\
\hline Eedulavanka & 4.4 & 5230.0 & 1174.4 & 8.9 & 7720.0 & 866.7 & 4.5 & 4990.0 & 1120.5 & Nil \\
\hline T-kothapally & 2.0 & 2150.0 & 1062.1 & 7.7 & 7090.0 & 921.7 & & & & Nil \\
\hline
\end{tabular}

Table.7 Crop water use efficiency before inception of Community based

Sprinkler irrigation system

\begin{tabular}{|c|c|c|c|c|c|c|c|c|c|}
\hline \multirow{2}{*}{ Village } & \multicolumn{9}{|c|}{ Yields before CBSIS } \\
& \multicolumn{3}{|c|}{ Fully Irrigated } & \multicolumn{3}{c|}{ Rainfed Cultivation } \\
\hline & $\begin{array}{c}\text { Area under } \\
\text { Irrigation } \\
\text { (ha) }\end{array}$ & $\begin{array}{c}\text { Yield } \\
\text { (kg) }\end{array}$ & Yield (kg/ha) & WUE & $\begin{array}{c}\text { Area under } \\
\text { rainfed } \\
\text { cultivation (ha) }\end{array}$ & $\begin{array}{c}\text { Yield } \\
\text { (kg) }\end{array}$ & $\begin{array}{c}\text { Yield } \\
\text { (kg/ha) }\end{array}$ & WUE \\
\hline Yerraguntla & 4.86 & 2300 & 473.42 & 1.46 & 4.05 & 1600 & 160.0 & 0.49 \\
\hline Eedulavanka & 8.91 & 8450 & 948.70 & 2.93 & 3.64 & 1300 & 144.4 & 0.44 \\
\hline T-kothapally & 2.43 & 2320 & 955.07 & 2.94 & 3.44 & 1020 & 120.0 & 0.37 \\
\hline
\end{tabular}


Table.8 Crop water use efficiency after inception of community based

Sprinkler irrigation system

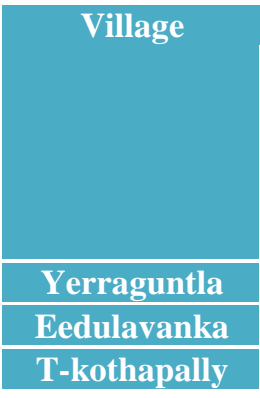

\begin{tabular}{|c|c|c|c|c|c|c|c|c|c|c|c|}
\hline \multicolumn{12}{|c|}{ Area under rainfed or critical irrigation after CBSIS } \\
\hline \multicolumn{4}{|c|}{ Fully irrigated } & \multicolumn{4}{|c|}{ Two critical irrigations } & \multicolumn{4}{|c|}{ Three critical irrigations } \\
\hline $\begin{array}{c}\text { Area } \\
\text { Fully } \\
\text { Irrigated } \\
\text { (ha) }\end{array}$ & $\begin{array}{c}\text { Yield } \\
\text { (kg) }\end{array}$ & $\begin{array}{l}\text { Yield } \\
\text { (kg/ha) }\end{array}$ & $\begin{array}{c}\text { WU } \\
\mathbf{E}\end{array}$ & $\begin{array}{c}\text { Area } \\
\text { under } \\
\text { CI } \\
\text { (ha) }\end{array}$ & $\begin{array}{c}\text { Yield } \\
(\mathbf{k g})\end{array}$ & $\begin{array}{l}\text { Yield } \\
\text { (kg/ha) }\end{array}$ & $\begin{array}{c}\text { WU } \\
\mathbf{E}\end{array}$ & $\begin{array}{c}\text { Area } \\
\text { under } \\
\text { CI } \\
\text { (ha) }\end{array}$ & $\begin{array}{c}\text { Yield } \\
\text { (kg) }\end{array}$ & $\begin{array}{c}\text { Yield } \\
\text { (kg/ha) }\end{array}$ & WUE \\
\hline 2.43 & 3560 & 1465.5 & 4.5 & 17.0 & 15540.0 & 913.9 & 2.8 & & & & \\
\hline 4.45 & 5230 & 1174.4 & 3.6 & 8.9 & 7720.0 & 866.7 & 2.7 & 4.45 & 4990.0 & 1120.5 & 3.4 \\
\hline 2.02 & 2150 & 1062.1 & 3.3 & 7.7 & 7090.0 & 921.7 & 2.8 & & & & \\
\hline
\end{tabular}

Fig.1 Location map of Ananthapur district of Andhra Pradesh
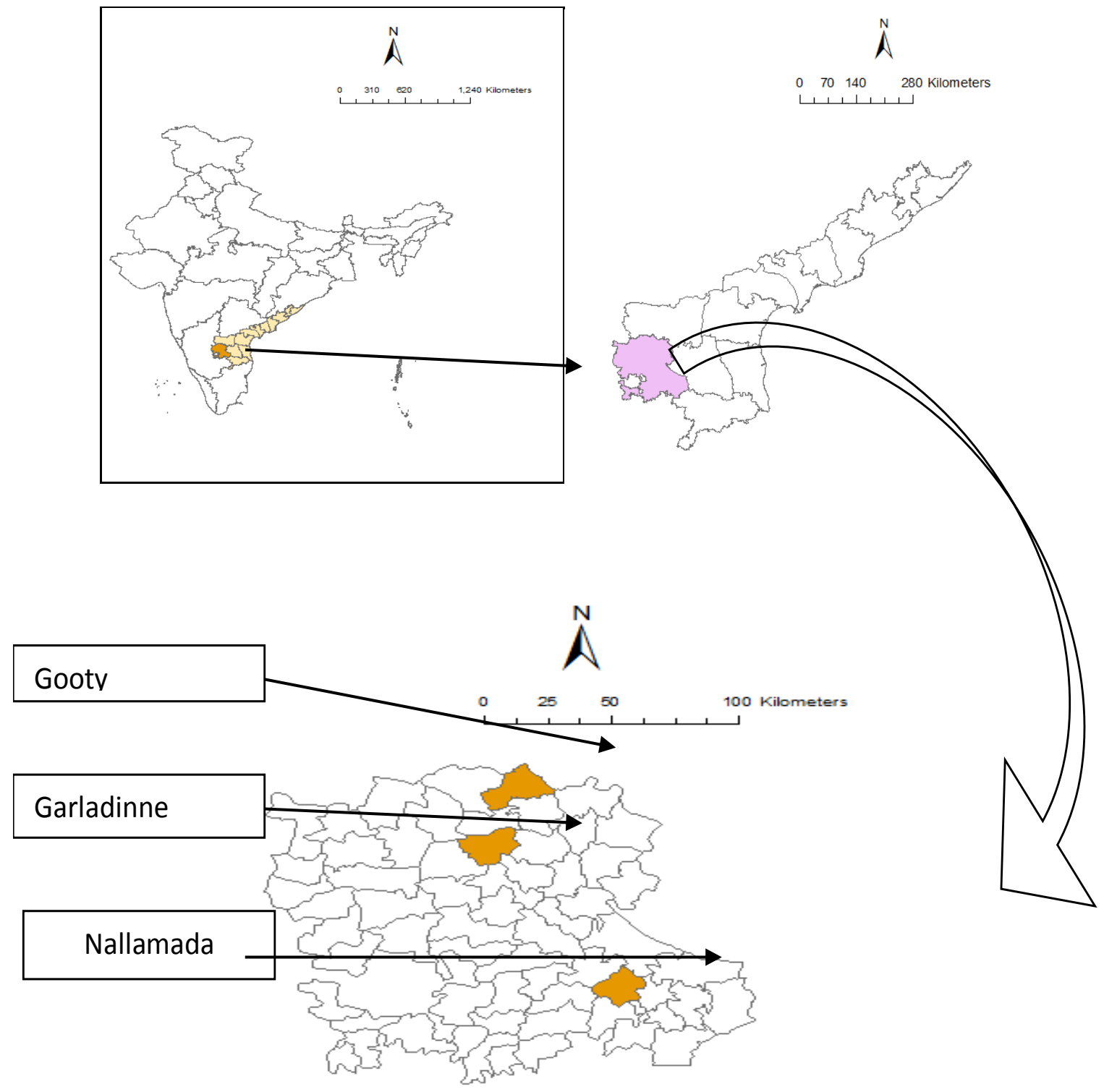


\section{Plate.1 Interview with farmers of Yerraguntla group}

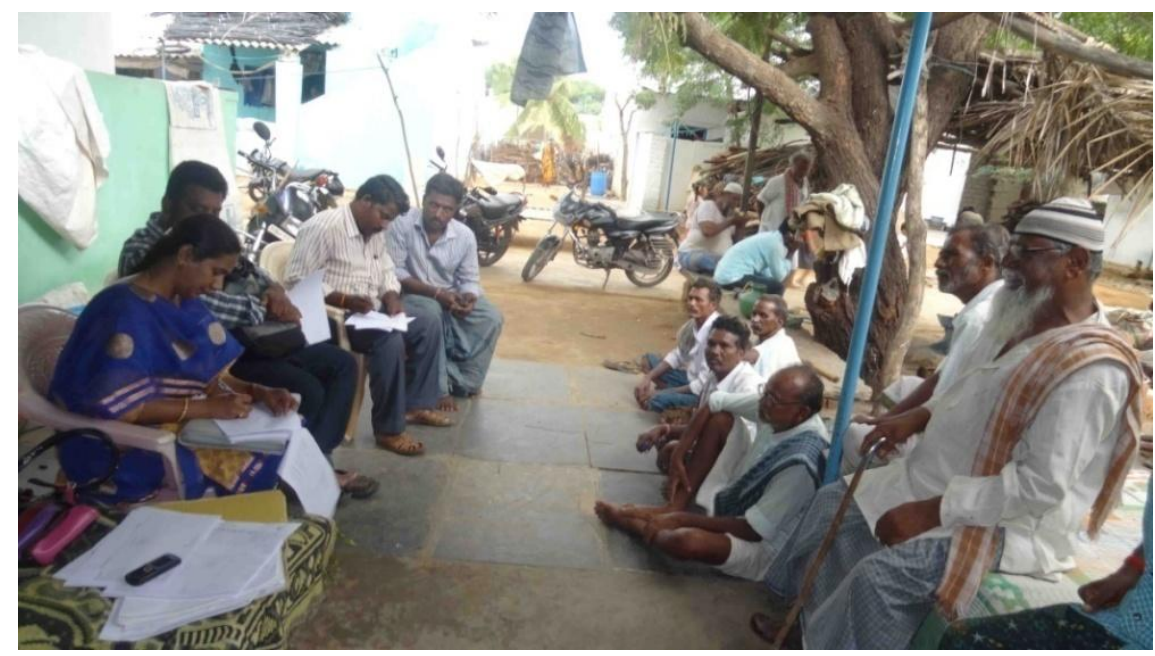

A committee has been formed with 3 members for each group for fund management and conflict resolution.

The members are 2 from the farmers group and one from the PFA which is working for the particular group. NGOs should organize, frequent interactions among group members for timely resolving of issues which may affect the integrity of the individual and the sustainability of the community (Feeny, 1990).

Recommendations for possible increase in area under CBSIS and its sustainability

Assistance from the government

Govt. has to extend the projects to cover all the semi-arid regions to convert barren land to minimum yield guaranteed zone and facilitate the farmers to earn their livelihood.

Timely release of the fund is needed to assist NGO's to work with full potential and with sufficient man power. Economic incentives and subsidies affect the choices on irrigation technology, crop mix especially in arid regions under various levels of water shortage (Ward, 2014; Braimah et al., 2014).
Instead of ordinary sprinkler irrigation system, Govt. can sanction rain guns, drip irrigation system and automated control valves to increase the irrigation potential and efficiency. Installing smart irrigation technology may require additional costs to upgrade older irrigation systems. Smart irrigation systems responds to weather and moisture content in the soil and thus adjusting the amount of water provided which further reduces water use by 20 percent (ILG, 2012).

Accustom of computerized control over irrigation using solar pumps and solar panels can improve the efficiency and sustainability (Clark et al., 2005)

Sustainability of the water sharing groups can be maintained only if any law is made on groundwater sharing since ground water is not the property of land owner.

Competitive digging of borewells, over extraction and wasting of groundwater should be monitored and penalized.

This is possible only through the linkup between all the central and state government departments through their key recommendations by conducting the national 
conferences to strengthen the links between practice and research (Garduno et al., 2011).

Incentives, awards and rewards should be introduced for encouraging the efficient use of water and encourage CBSIS groups (Wang et al., 2005).

Prioritize the CBSIS participant farmers in providing crop loans and other departmental schemes.

Motivating the BWO to share water to the adjacent farmers during rabi season.

State government is providing free electricity scheme for the farmers which are saddled with a threat of over exploiting the ground water (Garduno et al., 2011) besides wastage of electricity and water. Pumping energy efficiency and supply energy efficiencies to be studied to further improve the CBSIS performance. Similar studies done by the government of Spain to develop energy strategy for water users association reported that though they are not adequate to analyze the energy conservation, they must be used to propose measures for energy conservation (Abadia et al., 2010).

\section{Responsibilities of the participant community members}

Sustainability of community irrigation depends on the availability of the ground water. CBSIS aims to ensure sustainable outcomes from natural resource management through the involvement of local communities (Armitage, 2005; Gruber, 2010; Poteete, 2009). Sustainability of the CBSIS groups by following guidelines of operation, maintenance of the system and assessing the availability of groundwater. Intense precipitation events that are widely observed to be occurring, even in places where total precipitation is decreasing. In turn, this increases the risk of flooding (Trenberth, 2005). Heavy down pour of rains results in erosion and hence proper rainwater harvesting techniques needs to be adapted to recharge groundwater. Rainwater harvesting is the panacea for rainfed farming.

The impact of climate change is intensifying day by day which is to be addressed through policy perspective at the earliest to avoid short term effect such as yield and income loss and long-term effects like quitting of agricultural profession by the rainfed farmers (latha et al., 2012). The community as a whole should work for equity, empowerment, participation and conflict resolution, as per local conditions.

Comparing the three groups, only Yerraguntla group has to plan operating schedules carefully as $87 \%$ of the group area is of NBWO whereas Eedulavankais $50 \%$ and in Tkothapallyis $75 \%$. Yerraguntla group has experienced negligible yields in 18.3ha around $48 \%$ of the total group area. Edulavanka and T-Kothapally could get complete land under cultivation and could draw minimum yields by providing critical irrigation.

It is observed that in Eedulavanka, the irrigation requirement for the total group can be met in 2 days and the remaining 8 days irrigation is not required since the frequency of irrigation according to the type of soil and the root zone depth of the soil is 10 days. Therefore, it is advisable to diversify the crop and adapt drip irrigation system at least in bore well owners fields. Similarly, Tkothapally group can be irrigated within 4 days and irrigation frequency is 10 days. Hence crop diversification with drip irrigation system is recommended. All the farmers are growing the same crop in the 3 groups instead, depending on the recharge rate of ground water, farmers can diversify the crop. 


\section{References}

Abadia, R., Rocamora, M.C., Corcoles, J.I., Ruiz Canales, A., Romero Martinez, A. and Moreno, M.A. (2010). Comparative analysis of energy efficiency in water users associations. Spanish journal of Agricultural Resesrch, 8(S2), S 134 - S 142.

Agrawal, Sustainable governance of commonpool resources: context, methods, and politics, Annu. Rev. Anthropol. 32 (2003) 243-262.

Agricultural distress: A case study of Ananthapur District. M.S. Swamynathan Research Foundation, Chennai. MSSRF/RR/10/24.

Armitage, D. (2005). Adaptive capacity and community-based natural resource management. Environ Manage, 35:703715.

Bedeke, S.B. (2011). Community-based Irrigation Water Management System: the Case of Deder District, East Hararghe, Ethiopia. Advances in Physics Theories and Applications. ISSN 2224-719X (Paper), ISSN 22250638 (Online) Vol: 1.

Braimah, I., King, R. S. and Sulemana, D. M. (2014).Community-based participatory irrigation management at local government level in Ghana. Commonwealth Journal of Local Governance. Issue: 15

Daniel, A. (2011). Groundwater Reform in India: An Equity and Sustainability Dilemma. Texas International Law Journal. Vol. 46:623.

Deepika, S. (2016). Imact assessment of community based micro irrigation system of Ananthapur district. (Unpublished M.Tech thesis). Indira Gandhi Krishi Vishwavidyalaya, Raipur.

Feeny, D., Berkes, F., McCay J.B. and Acheson, M.J. (1990). The Tragedy of the Commons: Twenty-Two Years Later. Human Ecology, Vol. 18, No. 1.

Gadgil, S., Rao, P.R.S., Sridhar, S., (1999). 'Modelling Impact of Climate Variability on Rainfed Groundnut', Vol 76.No. 4, Current Science.

Gruber, J.S. (2010). Key principles of community-based natural resource management: a synthesis and interpretation of identified effective approaches for managing the commons. Environ Manage, 45:52-66.

Hector, G., Saleem, R., Buba, S., Albert, T. and Richard, D. (2011). India Groundwater Governance Case Study. Water Papers.

Hill, R.W. and Heaton, K. (2001).Sprinklers, crop water use and irrigation time. Utah State Uni. Co-oper. Ext. Ser. Bulletin. ENGR/BIE/WM/11.

James, C.J., Michael T.P. and David, S., (2005).Water Irrigation System and Method of Controlling Irrigation with Community Irrigation Instructions.United States Patent Application Publication. Pb.No.: US 2005/0211793 A1. Pub Date: Sep.29, 2005.

Latha K.V.A., Munisamy, G. and Bhat, A.R.S. (2012). Impact of Climate Change on Rainfed Agriculture in India: A Case Study of Dharwad. International Journal of Environmental Science and Development, Vol. 3, No. 4.

Michael, A.M., (2014). Irrigation Theory and Practice.

Montoro, A., Fuster, P.L.P. and Fereres, E. (2011). Improving on-farm water management through an irrigation scheduling service. Irrig. Sci. 29:311319.

Narayanamoorthy, A. (2003). Adverting water crisis by Drip method of irrigation: A study of two water intensive crops. Indian Journal of 
Agricultural Economics. Vol. 58. No.3. July-Sept.

Ortega, J.F., Juan J.A.D, Tarjuelo, J.M., (2005). Improving water management: The irrigation advisory service of Castilla-La Mancha (Spain). Agricultural Water Management, 77, 37-58

Ostrom, E. 1990.Governing the Commons: The Evolution of Institutions for Collective Action. Cambridge, MA: Cambridge Univ. Press

Ostrom, E. 1997.Self-governance of common pool resources. W97-2, Workshop in Political Theory and Policy Analysis, Indiana Univ., Bloomington

Patrina D. (2010). Community-based adaptation: enhancing community adaptive capacity in Druadrua Island, Fiji. Focus Article. John Wiley \& Sons, Ltd. Volume 1, September/October.

Poteete, A.R. (2009). Defining political community and rights to natural esources in Botswana. Dev Change, 40:281-305.

Rukmani, R. and Manjula, M. Designing Rural Technology Delivery Systems for Mitigating Agricultural Distress: A Study of Ananthapur District. M S Swaminathan Research Foundation. MSSRF/RR/10/24.

Sivanappan, R.K. (1998), "Irrigation Water Management for Sugarcane", in VSI, pp. II 100 - II 125.

Smart Irrigation Technology Stories - Three Communities, Three Experiences.
(2012). Institute for Local Government (ILG).www.ca-ilg.org/Sustainable Communities. To access this resource directly, go to www.ca-ilg.org/Smart IrrigationTechnology.

Smith, M. and Munoz, G., 2002. Irrigation Advisory Services for effective water use: a review of experiences. Workshop on Irrigation Advisory Services and Participatory Extension in Irrigation Management, FAO-ICID. Proceedings on line: 24th July, Montreal

Trenberth E. K. (2005). The Impact of Climate Change and Variability on Heavy Precipitation, Floods, and Droughts. Encyclopedia of Hydrological Sciences.

Umma, H., Rajib, S. and Yukiko, T. (2012). Farmers perception and adaptation practices to cope with drought: perspectives from northwestern Bangladesh. International Journal of disaster Risk Reduction, Vol. 1(1):7284.

Wang, Jinxia, Xu, Zhigang, Huang, Jikun, Rozelle and Scott. (2005). Incentives in water management reform: assessing the effect on water use, production and poverty in the Yellow River Basin. Environment and Development Economics 10, 769-799.

Ward, F.A. (2014). Economic impacts on irrigated agriculture of water conservation programs in drought. Journal of Hydrology, 508: 114-127.

\section{How to cite this article:}

Rao, K.V., S. Deepika and Rejani, R. 2018. Community Based Borewell Irrigation Systems for Improving Productivity and Water Use Efficiency in Dryland Agriculture. Int.J.Curr.Microbiol.App.Sci. 7(11): 526-539. doi: https://doi.org/10.20546/ijcmas.2018.711.063 